\title{
IMPLEMENTASI AKAD WAKALAH BIL UJRAH DALAM PELIMPAHAN WEWENANG PENYELENGGARAAN PERNIKAHAN PERSPEKTIF HUKUM EKONOMI SYARIAH (Studi Analisis Pada Shahira Islamic Wedding Organizer Surabaya)
}

\author{
Mochammady El Akbar \\ Muhammad Arfan Mu'ammar \\ Universitas Muhammadiyah Surabaya \\ Email : ady.livio@gmail.com
}

\begin{abstract}
Wakalah bil ujrah covenant implementation is an agreement covenant of an authority delegation to do something (delegating an affair) in which the implementation can be implemented in the field of wedding exertion by a wedding organizer. But generally, in the field implementation, the society has not been fully acknowledge and understanding how this implementation of an authority delegation in a wedding exertion accords with the the things which have been appointed by the syari'a economic law, and the legal consequences from the achieved wakalah agreement.

The problems formulation of this thesis is how the form of the wakalah covenant implementation and also the system of the ujrah taking in the authority delegation of a wedding exertion by Shahira Wedding Organizer Surabaya and analyzing the implementation based on the syari'a economic law of the National Syari'a Board - Majelis Ulama Indonesia (DSN-MUI).

This Study was conducted using online research instruments (online field research) with qualitative method. As for the data collecting techniques were done and achieved by online, observation, and the documentation data that are in correlate to the object of the study. The collected data, furthermore is arranged and analyzed using descriptive analysis method, it is describing how the akad wakalah bil ujrah implementation concept in obligating the authority the wedding exertion is done from the shahibbul hajat to Shahira Wedding Organizer Surabaya.

The results of the research show that the wakalah bil ujrah covenant implementation in delegating the authority from the shahibbul hajat to Shahira Wedding Organizer Surabaya is done orally through the agreement in choosing the packages of Gumush, Altin, and Platin using simple statements (informal language) as the Surabaya's people do. Furthermore it will be followed by some representation acts by the Shahira Wedding Organizer Surabaya. Dealing with the ujrah or the fee taking, it will be alocated and included into the price-list of the packages that automatically when it was on the first offer, the value of ujrah has been written and agreed. According to the perspective of the syari'a economic law, this wakalah bil ujrah practice done by the Shahira WO has fulfilled the well conformity in the implementation for the whole components between the both sides have been fulfilled in both of the pillars and the requirements that have been set by the Fatwa DSN-MUI No. 10/DSN-MUI/IV/2000 about wakalah.
\end{abstract}

Keywords : Wakalah Bil Ujrah, Wedding Organizer and Syari'a Economic Law Perspective

\section{A. PENDAHULUAN}

Islam mengatur segala sendi-sendi kehidupan manusia termasuk dalam persiapan dan pelaksanaan pernikahan. Pernikahan merupakan perintah Allah SWT untuk menyatukan dua insan dalam ikatan suci mahligai rumah tangga ${ }^{1}$ serta ayat-ayat lainnya yang menjelaskan pernikahan dalam Al-Qur'an maupun hadist-hadist Rasulullah

\footnotetext{
${ }^{1}$ Andi Syahraeni, Al-Qur'an, 24:32 dalam Jurnal AlHikmah Vol. XIX no. 2/2017.
}

SAW. ${ }^{2}$ Pernikahan merupakan media utama untuk membangun kehidupan masyarakat (eksistensi manusia) sebagaimana pilar membangun masyarakat ialah melalui pilar keluarga dan pilar agama. $^{3}$

\footnotetext{
2 Hadist-Hadist Keutamaan Menikah dalam https://umma.id.

3 Mohammad Fauzil Adhim, Kupinang Engkau Dengan Hamdalah, (Yogyakarta : Mitra Pustaka, Juni 1999), 5.
} 
Penyelenggaraan pernikahan yang diwakilkan hendaknya selaras dengan aturan Allah SWT sebagaimana kerap terjadi perilaku diluar aturanNya seperti di daerah pedesaan jawa (kejawen) masih kental adanya sesajen dan nuansa berbau klenik dalam persiapan serta pelaksanaan acaranya dimana hal ini merupakan penyimpangan dari perintah Allah SWT. ${ }^{4}$

Sesuatu yang syar'i dan tidak syar'i menjadi pemandangan sehari-hari. Pengaruh latar belakang keluarga, pendidikan, budaya, adat istiadat dan kepatuhan pada ajaran agama serta faktor external seperti pengaruh budaya asing serta hegemoni dunia barat yang liberal tanpa disadari turut merubah pola pikir serta perilaku masyarakat Indonesia yang menjunjung tinggi budaya, agama dan adat istiadat ketimuran yang telah berlangsung lama. ${ }^{5}$

Pergeseran norma, etika serta cepatnya akses digital membuat masyarakat perkotaan cenderung berperilaku instan, mementingkan diri dan ingin serba cepat. Karakter masyarakat perkotaan tersebut mengakibatkan minimnya pengetahuan \& kemampuan terhadap sesuatu yang berkaitan dengan konteks pernikahan bersumber dari khasanah budaya daerah tertentu maupun dari ajaran Islam.

Banyak jasa wedding organizer yang menyelenggarakan acara pernikahan bernuansa budaya daerah tertentu dikarenakan permintaan. Begitu pula dengan pelaksanaannya kerap diselipkan dengan segala praktik-praktik yang tidak sesuai dengan perintah Allah SWT seperti halnya klenik, syirik dan bid'ah.

Umumnya banyak urusan penyelenggaraan pernikahan diserahkan dengan mewakilkan pengurusannya kepada pihak lain. Hadirnya jasa wedding organizer tentu akibat yang dipengaruhi oleh faktor-faktor diatas sekaligus menjadi solusi bagi masyarakat yang membutuhkan jasa ini. Tidak sedikit jasa wedding organizer yang menjalankan implementasinya tidak sesuai dengan prinsip-prinsip syariah. Pada konteks keuangan misalnya, transaksi masih lekat dengan nuansanuansa mark-up biaya dan tidak transparan.

\footnotetext{
${ }^{4}$ Pajar Hatma Indra jaya, Dinamkia Pola Pikir Orang Jawa di Tengah Arus Modernisasi, Jurnal Humaniora, Volume 24, 2 Juni 2012, 133-140.

5 Pajar Hatma Indra jaya, Dinamkia Pola Pikir Orang Jawa di Tengah Arus Modernisasi, Jurnal Humaniora, Volume 24, 2 Juni 2012, 133-140.
}

Implementasi perwakilan (wakalah) yang dilaksanakan oleh suatu jasa wedding organizer yang selama ini berjalan belum sepenuhnya dipahami oleh pelaku jasa tersebut karena sistem yang dijalankan di design secara mandiri. Bahkan tidak sedikit yang tidak mengetahui akad wakalah bil ujrah meskipun pada dasarnya mereka telah melakukan dasar-dasar praktik dalam implementasinya.

Kerap terjadi tindakan-tindakan merugikan masyarakat yang hendak melangsungkan pernikahan disebabkan ketidakjelasan pada praktik perwakilan untuk penyelenggaraan pernikahan sehingga terdapat celah dimana praktik-praktik menyimpang dapat dilakukan seperti halnya penipuan-penipuan berkedok jasa perwakilan penyelenggaraan pernikahan. ${ }^{6}$

Implementasi perwakilan oleh jasa wedding organizer menghendaki pengambilan ujrah / upah dari shahibul hajat sebagai pihak yang mewakilkan penyelenggaraan pernikahannya tentu selama ini belum diketahui penentuan serta kesesuaiannya pada implementasi akad wakalah yang ditetapkan oleh Fatwa Dewan Syariah Nasional - Majelis Ulama Indonesia (DSN-MUI) nomor. 10/DSN-MUI/IV/2000.

Pedoman implementasi akad wakalah bil ujrah konteksnya pada jasa wedding organizer belum diberikan aturan khusus oleh Fatwa Dewan Syariah Nasional - Majelis Ulama Indonesia (DSN-MUI), hal ini berdampak pada ketiadaan aturan khusus mengenai implementasi sistem perwakilan yang dilakukan oleh banyaknya jasa wedding organizer yang saat ini sangat marak, berkembang dan semakin eksis di masyarakat.

Fatwa mengenai wakalah bil ujrah telah ada dengan fokus pada perusahaan asuransi syariah dan reasuransi syariah dengan nomor. 52/DSN-MUI/III/2006. ${ }^{7}$ Meski demikian penilaian terhadap kesesuaian implementasi yang dilakukan suatu wedding organizer tetap dapat dinilai dengan melihat substansi dari isi Fatwa tersebut.

Mengingat fokus implementasi wakalah bil ujrah dengan konteks jasa wedding organizer ini memiliki konsekuensi yang luas yaitu tidak hanya membicarakan seputar implementasi pada perwakilan serta pengambilan ujrah-nya saja,

\footnotetext{
6 Penipuan Wedding Organizer dalam https://www.detik.com/tag/wedding-organizer-penipu 7 Jurnal Ekonomi Syariah Teori dan Terapan (JESTT) UNAIR, Vol. 7 No. 10, Oktober 2020. 1944-1960.
} 
tetapi juga mengikat hingga pada bagaimana penerapan prinsip-prinsip syariah dalam perhelatan acaranya.

Sebagaimana contoh dibawah ini, mulai dari syarat-syarat yang diperlukan untuk persiapan pelaksanaan akad wakalah bil ujrah antara pihak wedding organizer (waqil) dengan shahibul hajat (muwaqil) yang wajib memenuhi kesesuaian hingga pada tahap pelaksanaan acara seperti pada etika makan dan minum yang umumnya dilakukan dengan cara berdiri, entertainment yang menyajikan lirik-lirik lagu yang tidak senada dengan tema pernikahan serta tidak mencerahkan, bercampurnya antara tamu laki-laki dan perempuan, etika berbusana pengantin wanita yang mungkin menggunakan uniform ketat dan cukup terbuka sehingga menunjukkan lekuk tubuh, etika dalam memberikan doa kepada pengantin yang tidak sesuai tuntunan Rasulullah SAW hingga pelaksanaan pernikahan yang dilaksanakan dengan kemasan-kemasan yang tidak sesuai dengan syariat Islam.

Umat Islam sebagai mayoritas di negeri ini sebagaimana perintah Allah SWT mutlak hukumnya menjalankan aturan-aturan Islam yang mana tujuan akhirnya ialah kemaslahatan. Segala instrumen akad transaksi dalam disiplin Hukum Ekonomi Syariah masih sedikit dikenal masyarakat khususnya konteks wakalah bil ujrah. Sistem konvensional yang masih dominan turut mempengaruhi perkembangan hukum ekonomi syariah di Indonesia.

Berdasarkan latar belakang yang telah penulis ungkapkan diatas maka, terdapat masalah yang akan penulis teliti yaitu :

1. Bagaimana implementasi sistem akad wakalah bil ujrah dalam pelimpahan wewenang penyelenggaraan pernikahan pada Shahira Islamic Wedding Organizer Surabaya?

2. Bagaimana implementasi akad wakalah bil ujrah dalam pelimpahan wewenang penyelenggaraan pernikahan pada Shahira Islamic Wedding Organizer Surabaya menurut perspektif Hukum Ekonomi Syariah?

Adapun Tujuan dalam penelitian ini dimaksudkan untuk :

1. Mengetahui bagaimana implementasi sistem akad wakalah bil ujrah dalam pelimpahan wewenang penyelenggaraan pernikahan pada Shahira Islamic Wedding Organizer Surabaya

2. Mengetahui implementasi sistem akad wakalah bil ujrah dalam pelimpahan wewenang penyelenggaraan acara pernikahan menurut perspektif hukum ekonomi syariah menurut Fatwa Dewan Syariah Nasional - Majelis Ulama Indonesia (DSN-MUI)

\section{B. LANDASAN TEORI \\ Pengertian Wakalah.}

Akad Wakalah ialah akad pemberian kuasa / pengalihan kewenangan dalam hal harta dan perbuatan tertentu dari seseorang kepada orang lain untuk mengambil tindakan/mengerjakan sesuatu sesuai yang disepakati bersama. ${ }^{8}$

Wakalah juga merupakan, pencukupan (alkifayah), tanggungan (al-dhamah) serta perlindungan al-hifz. Wakalah atau wikalah dapat diartikan pula sebagai mendelegasikan, menyerahkan, atau memberikan mandat / amanat. Dalam bahasa arab, wakalah dipahami sebagai at tafwidh seperti ungkapan kalimat "relegation of matters to god" yang artinya aku serahkan urusanku kepada Allah.

\section{Jenis-jenis Wakalah.}

Jenis-jenis wakalah mengacu pada karakteristik perannya yang berbeda, yakni pada sisi pendelegasian dan kewenangannya, adapun akad wakalah terbagi menjadi 2 (dua) jenis, antara lain yaitu: ${ }^{9}$

1. Wakalah al-Khosshoh adalah wakalah yang mana proses pendelegasian wewenang untuk menggantikan sebuah posisi pekerjaan yang bersifat spesifik / detail dan spesifikasinya telah jelas, contohnya : membeli handphone merk $X$

2. Wakalah al-'Ammah adalah akad wakalah yang mana proses pendelegasian wewenang bersifat umum, tanpa adanya spesifikasi. Contohnya : "Belikan saya makanan apa saja "

Selain itu, terdapat perbedaan juga pada wakalah al-Muqoyyadoh dan wakalah Mutlaqoh. Al-Wakalah al-Muqoyyadoh adalah adalah akad wakalah yang mana wewenang dan tindakan waqil dibatasi dengan syarat-syarat tertentu. Misalnya : " Jualkan rumah saya dengan harga

\footnotetext{
${ }^{8}$ Gemala Dewi, Wirdyaningsih, Yeni Salma Narlinti, Hukum Perikatan Islam di Indonesia, (Depok: Prenada Media Group, 6 Februari 2020), 54.

9 Tokimachi, Artikel: Wakalah, dalam https://smjsyariah89.wordpress.com/2012/04/24/wakal $a h /(4$ April 2012)
} 
300 juta rupiah jika tunai dan 350 juta rupiah jika pembelian secara kredit."

Wakalah al-Muthlaqoh, akad wakalah yang mana wewenang dan waqil tidak dibatasi dengan syarat atau kaidah tertentu, misalnya : “Jualkan rumah ini, tanpa menyebutkan harga yang diinginkan."

\section{Landasan Hukum Wakalah.}

Landasan hukum Islam dalam mensyariatkan akad wakalah disebabkan manusia hakikatnya merupakan mahluk sosial, ia memerlukan bantuan orang lain khususnya dalam mengerjakan segala urusannya. Dikarenakan ketidakmampuannya yang sangat terbatas maka manusia sepatutnya memerlukan peran orang lain sebagai waqil untuk menggantikan dirinya dalam suatu pekerjaan.

Wakalah memiliki dasar hukum yang cukup banyak salah satunya pada surat An-Nisaa' ayat 35:

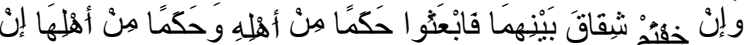

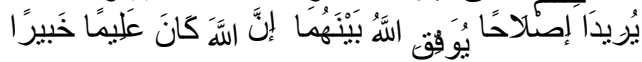

“ Dan jika kamu khawatirkan ada persengketaan antara keduanya, maka kirimlah seorang hakam dari keluarga laki-laki dan seorang hakam dari keluarga perempuan. Jika kedua orang hakam itu bermaksud mengadakan perbaikan, niscaya Allah memberi taufik kepada suami-isteri itu. Sesungguhnya Allah Maha Mengetahui lagi Maha Mengenal. "QS. An-Nisaa' 35. ${ }^{10}$

Ijma ulama membolehkan wakalah karena merupakan sikap tolong menolong / ta'awun antar sesama dilandasi kebaikan serta taqwa yang telah Allah SWT perintahkan kepada manusia maka, secara otomatis wakalah sangat dianjurkan. Allah SWT berfirman dalam Al-Qur'an yang berbunyi :

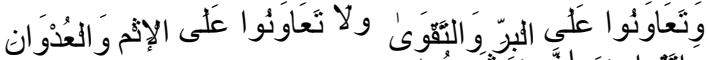

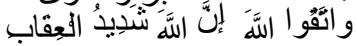

“ Dan tolong-menolonglah kamu dalam (mengerjakan) kebajikan dan takwa, dan jangan tolong-menolong dalam berbuat dosa dan pelanggaran. Dan bertakwalah kamu kepada Allah, sesungguhnya Allah amat berat siksa-Nya. "QS. Al-Maidah: 2. ${ }^{11}$

\footnotetext{
${ }^{10}$ Al-Qur'an, 4: 35

${ }^{11}$ Al-Qur'an, 5: 2.
}

\section{Rukun \& Syarat Wakalah}

Akad wakalah dalam penerapannya menyebabkan akibat hukum, maka rukun \& syarat wajib terpenuhi agar tercipta akad perjanjian yang memiliki keabsahan yang sempurna

Dalam wakalah tidak terdapat ketentuan pada lafadz-lafadz tertentu atau cara tertentu yang mengharuskan pelaksanaan akad menjadi baku, asalkan sesuai dengan kaidah-kaidah dalam ber ijab qabul seperti niat dan tujuan yang kuat dalam berakad, terpenuhi rukun dan syaratnya, lisan dan tulisan hingga pada sisi isyarat serta perbuatan.

Wakalah memiliki rukun dan syarat-syarat. Pengertian rukun ialah sesuatu yang mutlak, yang wajib ada pada suatu akad sedangkan syarat ialah adalah janji (sebagai tuntutan atau permintaan yang harus dipenuhi). Rukun dan syarat wakalah yang harus dipenuhi ialah $:^{12}$

1) Orang yang mewakilkan ( muwaqqil)

Dengan syarat orang tersebut merupakan pemilik urusan / benda dan menguasai keduanya serta dapat bertindak terhadap urusan / benda tersebut oleh dirinya sendiri. Syarat lainnya tentu orang tersebut dewasa/ baligh. Menguasai serta bertindak dalam hal ini artinya memiliki hak atau kewenangan mutlak.

2) Orang yang mewakili (waqil)

Syaratnya ialah ia merupakan orang yang mampu / berakal, dewasa / baligh, tidak gila/kurang akal, mampu pada segi kecakapan secara hukum, terampil, ahli pada bidangnya, dapat dipercaya dalam mengerjakan amanah / pekerjaan yang diwakilkan. Orang yang berstatus waqil, tidak diperkenankan untuk berwakil pada orang lain, terkecuali mendapat izin dari muwaqqil pertama, tetapi apabila secara terpaksa / memang secara sistem wakil memiliki wakil khusus, maka boleh berwakil pada orang lain dengan syarat tetap berkomunikasi dengan muwaqqil.

3) Sesuatu yang diwakilkan (mawwaqqal fih) Syaratnya antara lain ialah :

a. Pekerjaan itu dimiliki oleh muwaqqil sewaktu akad wakalah berlangsung.

\footnotetext{
${ }^{12}$ Galuh Vida Khumairoh, Renny Oktafia, Penerapan Akad Wakalah Bil Ujrah Pada Pengelolaan Produk Proteksi Kesehatan Di Prudential Syariah Cabang Sidoarjo, Jurnal Ekonomi Syariah Teori dan Terapan p-ISSN: 2407-1935, e-ISSN: 2502-1508. Vol. 7 No. 10 Oktober 2020: 1944-1960
} 
Dalam hal ini hak urusan tersebut murni dimiliki kewenanangannya oleh muwaqqil.

b. Pekerjaan / urusan dapat dilimpahkan / diwakilkan atau digantikan oleh orang lain. Terkecuali mewakilkan dalam hal-hal ibadah seperti shalat, membaca Al-Qur'an, puasa dsbnya.

c. Pekerjaan yang akan diwakilkan diketahui secara jelas, tidak samar.

d. Sighat, hendaknya / diupayakan terdapat lafal yang menegaskan " mewakilkan " dan diiringi kerelaan dari muwaqqil seperti halnya " saya wakilkan / limpahkan / serahkan pekerjaan ini kepadamu untuk mengerjakan pekerjaan ini. "

\section{Berakhirnya Wakalah}

Senada dengan berakhirnya suatu akad, akad wakalah dinyatakan berakhir atau tidak dapat berlanjut dikarenakan sebab-sebab tertentu seperti dibawah ini :

a. Meninggal dunia pada salah satu pihak yang berakad

b. Bila salah satu dari yang berakad hilang akal sehat / gila.

c. Pekerjaan yang diwakilkan dihentikan. Dihentikan oleh muwaqqil atau secara keseluruhan terhenti.

d. Pemutusan oleh muwaqqil terhadap waqil, meskipun waqil dalam keadaan tidak mengetahuinya (menurut Syafi'i dan Hambali), tetapi menurut Hanafi seorang waqil wajib mengetahui pemutusan tersebut, agar dapat menyesuaikan tindakan selanjutnya.

e. Waqil memutuskan sendiri. Menurut Hanafi tidak perlu muwaqqil mengetahuinya.

f. Keluarnya orang yang mewakilkan (muwaqqil) dari status kepemilikan hak / kewenangannya.

\section{Pengertian Wedding Organizer}

Wedding Organizer ialah jasa konsultan pernikahan yang secara profesional membantu calon pengantin beserta keluarga dalam merencanakan, mempersiapkan, menganggarkan dan suksesi pelaksanaan acara pesta pernikahan sesuai dengan agenda-agenda yang telah ditetapkan. ${ }^{13}$

Wedding organizer akan membantu yakni mengurangi beban calon pengantin dalam mempersiapkan penyelenggaraan acara dari awal hingga acara selesai secara efektif karena memiliki standard operational prosedure (SOP) dan akses serta pengalaman.

\section{Peran \& Tugas Wedding Organizer}

Berdasarkan pada ulasan diatas mengenai pengertian wedding organizer maka, peran wedding organizer secara global ialah :

a. Membantu dan meringankan beban calon pengantin \& keluarga.

b. Membantu dalam manajemen persiapan diantaranya memberikan gambaran, mengarahkan, menentukan konsep pernikahan dan mengelolanya hingga pelaksanaan.

c. Membantu menengahi dan menyatukan kedua keluarga calon pengantin.

d. Merekomendasikan berbagai vendor-vendor terbaik untuk fasilitas acara pernikahan kepada calon pengantin dan keluarga.

e. Membantu calon pengantin dan keluarga dalam menghemat biaya-biaya yang tidak diperlukan.

f. Bersama dengan seluruh timnya, membantu dan bersinergi dengan panitia keluarga dalam setiap tahapan persiapan (seringkali terdapat panitia persiapan sendiri yang dibentuk keluarga).

g. Pada pelaksanaan acara, peran wedding organizer memastikan pelaksanaan sesuai dengan rundown yang telah ditentukan.

h. Membantu mengamankan segala properti keluarga selama acara berlangsung, misalnya menjaga mahar.

i. Membantu penyelesaian manajemen biaya dalam penyelenggaraan pernikahan hingga akhir.

Sedangkan tugas wedding organizer secara spesifik dalam bekerja membantu kedua calon pengantin beserta keluarganya, yaitu : ${ }^{14}$

\footnotetext{
13 Calysta Wedding Organizer, Pengertian Wedding Organizer, dalam

https://calystawedding.wordpress.com/, November, 30, 2013.

14 Tugas wedding organizer dalam https://calystawedding.wordpress.com/
} 
a. Memberikan informasi yang detail kepada calon pengantin mengenai hal-hal yang harus diperhatikan dalam perencanaan dan pelaksanaan akad nikah hingga pelaksanaan resepsi / walimahan.

b. Memimpin pelaksanaan meeting.

c. Membantu perencanaan dan pemetaan mengenai tema, alur persiapan, skenario pada rangkaian acara, tema dekorasi pesta dan konsep pernikahan secara keseluruhan.

d. Menyusun budget / penganggaran \& proposal.

e. Merekomendasikan master of ceremony (MC) / pembawa acara.

f. Memfasilitasi, menegosiasi dan mengkoordinasi / follow up intensif dengan pihak gedung / hotel dan supplier / vendor.

g. Manajemen biaya pernikahan.

h. Monitoring pencapaian dalam persiapan pernikahan kepada pasangan pengantin dan keluarga.

i. Menghubungi intensif setiap rekanan / supplier / vendor untuk follow up dan update yang diperlukan.

j. Mengkoordinasikan persiapan akhir.

k. Memonitor rundown acara.

1. Mengingatkan jadwal pembayaran vendor dan semua elemen yang mendukung terlaksanannya acara.

m. Memberikan laporan tertulis (bilamana diperlukan) kepada pihak pengantin yang baru menikah beserta keluarga.

\section{METODE PENELITIAN}

Penelitian ini merupakan field study research berbasis penelitian deskriptif kualitatif; ialah penelitian yang bertujuan untuk membangun deskripsi secara teoritis, faktual dan akurat. ${ }^{15}$ Maka peneliti tentu menganalisis bagaimana bentuk penerapan akad wakalah bil ujrah oleh Shahira Wedding Organizer Surabaya dan dilakukan analisa deskriptif teoritis dengan kesimpulan apakah memiliki kesesuaian dengan perspektif hukum ekonomi syariah menurut Fatwa DSN-MUI tentang wakalah.

15 Nurus Salihen, Analisis Akad Musyarakah Pada Pembiayaan Modal Usaha Beragunan Emas Dalam Perspektif Hukum Islam (Studi kasus di PT. BPRS Mandiri Mitra Sukses, Gresik), Jurnal Justisia Ekonomika, Vol. 4 No. 1, Juni 2020.
Pendekatan fenomenologi merupakan metode yang menjadi dasar peneliti dalam melakukan penelitian, artinya realitas fenomena yang terjadi pada obyek penelitian berupa operasionalisasi \& implementasi akad wakalah bil ujrah berdasarkan perilaku, persepsi, motivasi, tindakan, dan sebagainya secara holistik dengan pemaparan deskripsi berbentuk narasi (kata-kata) pada konteks dan menggunakan metode ilmiah dalam menganalisa serta menjadi fokus utama yang akan diteliti. ${ }^{16}$

Sumber data pada penelitian ini berkaitan dengan Implementasi akad wakalah bil ujrah yaitu sistem pelimpahan wewenang penyelenggaraan pernikahan oleh Shahira Islamic Wedding Organizer Surabaya serta data mengenai implementasi sistem pembiayaan / ujrah yang diperoleh Shahira Wedding Organizer Surabaya.

Pengumpulan data dilakukan dengan 3 (tiga) cara yaitu melalui teknik wawancara secara daring dikarenakan dilaksanakan di masa pandemi covid19, teknik observasi di lapangan dan data-data dokumentasi sebagai informasi pendukung yang bersumber langsung dari obyek penelitian.

\section{HASIL \& PEMBAHASAN}

Implementasi Akad wakalah yang dilaksanakan oleh Shahira Islamic Wedding Organizer Surabaya termasuk kedalam jenis akad wakalah al khosshoh yaitu proses pendelegasian wewenang untuk menggantikan sebuah posisi pekerjaan yang bersifat spesifik, teknis dan detail.

Berdasarkan kewenangannya termasuk kedalam wakalah al-muqoyyadoh yang terbatas kewenangannya hanya pada penyelenggaraan pernikahan saja. Shahira termasuk dalam wakalah al-muthlaqoh dengan kewenangan yang tidak dibatasi meski tetap berorientasi pada ketentuan yang digariskan oleh shahibul hajat. Sebagai contoh Shahira Islamic Wedding Organizer Surabaya selalu berkoordinasi intensif dengan costumer ketika memtutuskan sesuatu, pihak costumer hakikatnya membebaskan Shahira untuk bertindak.

Segmen pasar Shahira fokus pada pasangan muslim muda yang menginginkan model pelaksanaan pernikahan dengan konsep islami,

${ }^{16}$ Salihen, Nurus, 2020. "Analisis Akad Musyarakah Pada Pembiayaan Modal Usaha Beragunan Emas Dalam Perspektif Hukum Islam (Studi Kasus di PT. BPRS Mandiri Mitra Sukses, Gresik), Jurnal Justisia Ekonomika, Vol. 4 No. 1, Juni 2020. 
tanpa ada prosesi yang bernuansa adat-istiadat yang tidak sesuai dengan syariat Islam dengan kemasan kekinian, modern, simpel, cantik dan elegan serta biaya yang terjangkau.

Setelah terbangun komunikasi antara costumer dengan Shahira Wedding Organizer, tujuan pertama dari proses ini ialah diskusi yang berkaitan dengan supply \& demand atau take and gift diantara kedua pihak.

Shahira Wedding Organizer bekerja berdasarkan paket. Terdapat dua paket utama di Shahira, yaitu paket wedding organizer dan paket pernikahan lengkap (wedding organizer dan seluruh vendor). Adapun jenis-jenis paket Shahira WO antara lain yaitu paket Gumush, Altin dan Platin.

Mekanisme terciptanya agreement / persetujuan \& perjanjian, terjadi bila telah tercapai kata sepakat untuk saling bekerjasama. Costumer telah sepenuhnya memahami letter of understanding, fasilitas \& benefit apa saja yang akan didapatkan dengan meng-hier Shahira. Inilah awal mekanisme dari akad wakalah bil ujrah terbangun.

Proses terjadinya akad perjanjian pelimpahan penyelenggaraan pernikahan terjadi berdasarkan paket yang dipilih oleh costumer (Gumush, Altin dan Platin). Ketika costumer telah memilih paket yang dikehendaki maka, Shahira Wedding Organizer memberikan invoice berupa nota pembayaran. Invoice menurut jurnal entrepreneur adalah dokumen yang digunakan sebagai bukti pembelian yang berisi jumlah pembayaran yang harus dibayarkan oleh pembeli. ${ }^{17}$

Senada dengan pengertian tersebut, pada Shahira Wedding Organizer, invoice menyediakan informasi item-item berupa fasilitas dari paket yang disepakati dengan sejumlah dana yang dapat dibayarkan costumer. Invoice dalam konteks ini menurut Shahira ialah sebagai tanda sah merajut ikatan perjanjian dan mengesahkan pernyataan lisan yang menyatakan kesediaan menggunakan jasa Shahira serta memberikan kepastian pada Shahira dalam perwakilan penyelenggaraan pernikahan.

Mekanisme pelaksanaan akad wakalah bil ujrah dilakukan dengan cara lisan dan diikuti dengan tindakan dimana pihak costumer

17 Jurnal Entrepreneur, Pengertian Invoice, dalam jurnal.id/idblog/trik-cerdas-memperoleh-invoicepembayaran-dengan-cepat/ menyatakan setuju menggunakan jasa layanan dari Shahira Islamic Wedding Organizer Surabaya untuk menguruskan penyelenggaraan pernikahannya.

Adanya persetujuan dari costumer dengan diikuti sejumlah pembayaran merupakan bentuk kepercayaan, kerelaan, keikhlasan dan pertanggungjawaban. Ini merupakan tujuan dasar dan niat dari pelaksanaan suatu akad / Maudhu al 'Aqd, bahwa costumer sepakat memilih paket tertentu dari Shahira Wedding Organizer dan Shahira berkewajiban menjadi wakil yang baik bagi costumer untuk mempersiapkan penyelenggaraan pernikahannya hingga selesai.

Konteks pelaksanaan akad wakalah bil ujrah yang dilakukan oleh Shahira Wedding Organizer apakah memiliki kesesuaian dengan rukun dan syarat dari pelaksanaan akad, maka analisis dibawah ini antara lain yaitu :

a. 'Aqid yaitu adanya orang yang melakukan akad. Dalam hal ini akad terjadi antara kedua pihak yaitu pihak shahibul hajat / costumer dengan pihak Shahira Islamic Wedding Organizer Surabaya.

b. Ma'qud 'Alaih, suatu benda-benda yang dapat diakadkan / diperjanjikan, yang dimaksud konteks ini ialah jasa layanan perwakilan penyelenggaraan pernikahan oleh Shahira Islamic Wedding Organizer Surabaya tentu jasa tersebut memiliki nilai

c. ekonomis. Dalam konteks kebendaan, jasa vendor yang tercantum pada paket-paket Shahira menjadi elemen terselenggaranya pernikahan tentu menyediakan sarana prasarana yang bernilai ekonomis dan tentu dapat diakadkan.

d. Maudhu' al- 'aqd, niat, tujuan serta maksud dari diadakannya akad ialah untuk suksesi penyelenggaraan pernikahan costumer oleh Shahira Islamic Wedding Organizer Surabaya sebagai waqil.

e. Ijab Qabul. Sighat al-aqd, terdapat proses ijab qabul, dalam konteks ini ijab qabul terjadi antara costumer dengan Shahira Islamic Wedding Organizer Surabaya.

Sedangkan berdasar syarat-syarat terjadinya akad wakalah bil ujrah antara costumer dengan Shahira Islamic Wedding Organizer Surabaya antara lain :

a. Tujuan akad antara shahibul hajat dengan Shahira memiliki landasan yang jelas, yaitu saling tolong menolong dalam 
penyelenggaraan pernikahan. Pihak costumer tidak memiliki keterampilan, pengalaman, akses link serta informasi yang di manajemen sepenuhnya oleh Shahira Islamic Wedding Organizer Surabaya.

b. Ijab qabul yang terjadi antara shahibul hajat dengan Shahira Islamic Wedding Organizer Surabaya memiliki maksud yang kuat dan jelas serta tidak terdapat keraguan diantara keduanya (mengedepankan kepercayaan). Keduanya saling membutuhkan satu sama lain, maksud dan tujuan yang jelas yaitu untuk membantu menyelenggarakan pernikahan.

c. Ijab dan qabul berbentuk lisan maupun secara tulisan (hitam diatas putih) dan melalui perbuatan serta isyarat tertentu. Dalam hal ini proses ijab qabul antara shahibul hajat dengan Shahira Islamic Wedding Organizer Surabaya berjalan secara lisan (kedua pihak menyatakan sepakat). Selain itu, ijab qabul juga diikuti dengan media tulisan, khusus pada konteks ini, tulisan yang dimaksud yakni perjanjian tertulis. Adapun media yang digunakan oleh Shahira WO ialah media invoice. Diikuti pula dengan perbuatan / tindakan dan isyarat (niat baik), secara teknis syaratsyarat pada implementasi ijab dan qabul terpenuhi.

Sesuai pemaparan unsur dan syarat akad diatas, maka pelaksanaan akad wakalah yang dilakukan oleh Shahira dengan shahibul hajat telah memenuhi syarat sahih nafiz. Dalam konteks subyek dan obyek akad, kedua belah pihak menjadi bagian dari obyek akad serta akibat hukum yang menyertai keduanya.

Akad wakalah yang terlaksana mengedepankan prinsip keadilan, kerelaan, kejujuran, tidak membebani, meringankan, membebaskan, serta sikap tolong-menolong.

Tindakan perwakilan penyelenggaraan pernikahan oleh Shahira Islamic Wedding Organizer Surabaya meliputi: ${ }^{18}$

a. Bermusyawarah dengan keluarga dan calon pengantin.

b. Mengelaborasi persiapan pernikahan pada shahibul hajat dan calon mempelai dengan cara memberikan gambaran pengayaan

18 Meyranti Kartika Puteri, Wawancara Daring, Surabaya, 17 Januari, 10, 23 Juni dan Jum'at, 17 Juli 2020 pukul 10.30 WIB. pada konsep, model, tema, dan pengkondisian pernikahan, teknis-teknis, dan lain sebagainya.

c. Menginformasi keluarga untuk pelaksanaan meeting, memimpin meeting antara keluarga dengan vendor-vendor.

d. Memberi arahan agar pelaksanaan pernikahan berjalan dengan semestinya.

e. Merancang proposal pernikahan, kepanitiaan, rundown acara pernikahan, mencatat data base person in charge (PIC) dari vendor-vendor.

f. Mengkoordinir tim Shahira Wedding Organizer oleh owner

g. Menghubungi pihak venue untuk teknis yang perlu dipersiapkan,

h. Merekomendasikan berbagai hal.

i. Menganggarkan pembiayaan dan memanage keuangan.

j. Menghubungi dan manajemen pihak-pihak dalam perhelatan seperti; catering, entertainment, venue, dekorasi, vendor foto dan video, MC / pembawa acara, sound system, lighting, dan lain-lainnya.

k. Mengagendakan \& mendampingi survey vendor; catering food test, survey vendor dekorasi, uniform test pada vendor rias pengantin dan gaun pernikahan serta vendor makeup artist.

1. Menyampaikan surat loading / surat perijinan untuk masuk ke dalam venue pada semua vendor.

m. Menyiapkan dan memastikan kesiapan semua vendor dengan observasi pada venue di minus 1 hari.

n. hingga tahap pelaksanaan acara, meeting akhir, cek kesiapan pelaksanaan akad nikah, cek point rundown acara, cek point kehadiran, dsbnya.

o. Memastikan pelunasan pembiayaan kepada seluruh vendor, MC, semua pihak yang terkait dalam pelaksanaan acara pernikahan costumer termasuk pada tim Shahira Islamic Wedding Organizer Surabaya.

p. Meeting akhir sebagai bentuk pelaporan pertanggungjawaban Shahira Wedding Organizer kepada pihak shahibul hajat terkait laporan keuangan, dan laporanlaporan lainnya.

Menganalisis program dari Shahira Islamic Wedding Organizer Surabaya dalam menjalankan perwakilannya perlu dipastikan kesesuaian 
implementasi akad wakalah berdasarkan tinjauan teori. Adapun implementasi akad wakalah oleh Shahira Islamic Wedding Organizer Surabaya dengan ketentuan meliputi :

a. Berdasar analisis Shahira Wedding Organizer Surabaya bekerja secara profesional, terprogram, berjalan sistematis dan efektif tentu hal ini disesuaikan dengan SOP Shahira.

b. Shahira Wedding Organizer Surabaya menjalankan perwakilan mendapatkan kuasa / wewenang langsung dari shahibul hajat / muwaqqil sebagai pihak yang sah memberikan mandat. Artinya secara kaidah fiqih mengenai keabsahan yang berkaitan dengan orang yang mewakilkan dan dikuatkan oleh terpenuhinya rukun-rukun dan syarat wakalah, akad wakalah yang dijalankan Shahira hukumnya sah.

c. Shahibul hajat merupakan pihak yang berhak untuk bertindak serta dikenakan akibat hukum dari tindakannya, artinya shahibul hajat pada hakikatnya dapat bertindak sendiri, tetapi dikarenakan satu dan lain hal maka mewakilkan urusannya kepada pihak lain. Maka secara kaidah fiqih mengenai wakalah, sah mendelegasikan urusannya kepada Shahira Wedding Organizer Surabaya. ${ }^{19}$

d. Berdasarkan rukun dan syarat akad wakalah tentang pihak yang mewakili, Shahira Wedding Organizer merupakan pihak yang ahli dan memiliki kapasitas, maka pada konteks ini Shahira Wedding Organizer sesuai dengan rukun dan syarat akad wakalah.

e. Shahira Wedding Organizer Surabaya bekerja dengan berpedoman kepada proses musyawarah yang dilaksanakan pasca pelaksanaan akad wakalah.

f. Muwakkal fih, adanya sesuatu yang diwakilkan. Pada konteks ini urusan tersebut ialah penyelenggaraan pernikahan, urusan yang dapat diwakilkan Artinya Shahira Wedding Organizer Surabaya memenuhi kriteria muwakkal fih .

g. Pekerjaan yang diamanatkan kepada Shahira Wedding Organizer merupakan pekerjaan yang jelas, tidak samar dan tidak

19 Abdul Rahman Ghazaly, Ghufron Ihsan, Sapiudin Shidiq, Fiqih Muamalat, (Jakarta: Prenadamedia Group, 2010), 189. menyalahi aturan syariah yaitu menyelenggarakan acara pernikahan dari shahibul hajat sebagai muwaqqil.

h. Sighat. Dalam konteks ini sesuai hasil wawancara antara peneliti dengan owner Shahira, bahwasanya pelaksanaan sighat / ijab qabul akad wakalah berjalan dengan media pemilihan paket-paket dari Shahira. Kedua belah pihak tidak menggunakan lafal baku yang disyariatkan seperti kata-kata "Saya wakilkan atau serahkan pekerjaan ini kepada kamu untuk mengerjakan pekerjaan ini" yang kemudian diterima oleh waqil. Berdasar analisis penggunaan narasi pada proses sighat ini hanya menggunakan kata-kata sederhana (non formal) yang secara harfiyah memiliki arti yang sama "mewakilkan" serta adanya akibat hukum dari kata ijab itu sendiri. Seperti contoh keluarga calon pengantin mempasrahkan sepenuhnya seluruh acara dengan pernyataan : "mbak, saya pasrahkan acara kami di mbak aja, sesuai paket yang kemarin dipilih" atau "mbak, saya minta tolong di handel aja semuanya, saya percayakan Shahira, pokoknya sesuai paket aja." Konteks jawaban dari Shahira juga memiliki maksud dari qabul / menerima yang intinya seperti; "Baik mbak, saya siapin semuanya" atau "iya siap, sesuai paket aja ya mbak, nanti saya aturkan yang bagus." Meskipun dengan lafal yang tidak baku (sesuai syariat) dengan berbagai versi ungkapan dan pernyataan, inti yang tercapai ialah terdapat kerelaan dan kepercayaan dari kedua belah pihak. Artinya menurut peneliti bahwa dalam konteks sighat, kedua belah pihak memenuhi rukun dari akad wakalah dan hukumnya sah.

i. Berakhirnya akad wakalah yang terjalin antara shahibul hajat dengan Shahira Wedding Organizer Surabaya terjadi dikarenakan pekerjaan yang diwakilkan kepada Shahira telah dilaksanakan. Dalam konteks ini Shahira benar-benar memelihara amanat dan kepercayaan dibuktikan dengan lamanya Shahira Wedding Organizer hadir dan memberi pelayanan kepada masyarakat dengan track record dari 30 Maret 2012 hingga Agustus 2020.

Implementasi Shahira Wedding Organizer dalam penentuan dan mekanisme pengambilan 
ujrah berupa upah (fee) dari jasanya melayani costumer dalam menyelenggarakan acara pernikahan, pengambilan ujrah dilakukan dengan pengalokasian biaya pendapatan yang masuk (include) pada paket Gumush, Altin, Platin, artinya nilai ujrah / fee porsinya masuk ke dalam paket-paket tersebut.

Fasilitas / benefit yang terdapat pada paket Shahira Wedding Organizer antara lain sudah termasuk biaya dari jasa wedding organizer berupa fee layanannya dan biaya seluruh vendorvendor pernikahan. Terkait nilai riil dalam wawancara bersama peneliti, Shahira Wedding Organizer menyebutkan nilai ujrah dalam bentuk persentase sebesar 5-7 \% dari biaya total keseluruhan dari paket. ${ }^{20}$

Ujrah yang diambil oleh Shahira Wedding Organizer merupakan biaya layanan penyelenggaraan pernikahan, menurut wawancara terdiri dari komponen-komponen biaya meliputi 21 .

a. Fee event seluruh team Shahira Islamic Wedding Organizer Surabaya.

b. Berbagai biaya yang terjadi seperti transportasi, akomodasi, biaya-biaya tidak terduga dan lainnya selama pengurusan penyelenggaraan pernikahan.

c. Surplus yang merupakan keuntungan bagi Shahira Islamic Wedding Organizer Surabaya.

Kaitannya pada pemberlakuan harga dan biaya, menurut hasil wawancara dengan Shahira Wedding Organizer, pihaknya tidak menerapkan pemberlakuan biaya dengan langkah mark-up. Konteks mark-up, memang lazim terjadi. Overcost ialah modus yang kerap dilakukan yakni mengonsumsi sumber daya dengan biaya rendah tetapi dilaporkan (kepada costumer) dengan biaya yang tinggi.

Shahira Wedding Organizer Surabaya tidak melakukan mark-up biaya dikarenakan bila markup diberlakukan akan mengakibatkan beban biaya / expense paket menjadi lebih tinggi.

Untuk mengatasi hal ini, Shahira tidak memark-up biaya, melainkan memberlakukan subsidi silang. Subsidi silang atau product cost cross

20 Meyranti Kartika Puteri, Wawancara, Chat Whatsapp, Surabaya, 10 Agustus 2020, pukul 08.20 WIB

21 Meyranti Kartika Puteri, Wawancara Daring, Surabaya, 19 Juli 2020 pukul 07.10 WIB. subsidization ialah pengalokasian biaya dari produk yang mengalami kelebihan biaya kepada produk yang kekurangan biaya. ${ }^{22}$

Konteks biaya ini berhubungan erat dengan atmosfer persaingan harga dengan wedding organizer lainnya. Shahira berupaya memposisikan diri / bargaining position menguatkan faktor nilai tawar sehingga memungkinkan masyarakat nantinya akan lebih memprioritaskan pilihannya kepada Shahira Islamic Wedding Organizer Surabaya sebagai waqil-nya dan meringankan beban masyarakat.

Implementasi Akad Wakalah Bil Ujrah oleh Shahira Wedding Organizer Surabaya menurut Perspektif Hukum Ekonomi Syariah

Analisis Hukum Ekonomi Syariah yang dimaksud adalah prinsip-prinsip syariah akad wakalah bil ujrah yang bersumber dari Fatwa Dewan Syariah Nasional - Majelis Ulama Indonesia (DSN-MUI) NO: 10/DSNMUI/IV/2000. ${ }^{23}$ Bagaimana implementasi akad wakalah bil ujrah yang diaplikasikan oleh Shahira Islamic Wedding Organizer Surabaya menurut pandangan dari fatwa DSN-MUI mengenai wakalah bil ujrah, meliputi :

a. Sebagaimana tujuan dari akad wakalah ialah sebagai bentuk tolong menolong. DSN-MUI menegaskan diperlukan pihak lain dalam rangka mencapai tujuan tertentu. Karenanya Shahira Wedding Organizer Surabaya hadir sebagai solusi untuk membantu masyarakat Kota Surabaya dalam menyelenggarakan acara pernikahan Shahira dalam hal ini sesuai dengan anjuran syariat menurut fatwa tersebut.

b. Akad wakalah bil ujrah harus dilaksanakan sesuai ajaran Islam. Shahira Wedding berdasarkan penelitian memiliki kesesuaian dengan syariat Islam dan melaksanakan akad wakalah bil ujrah dengan terpenuhi rukun dan syarat-syarat yang diatur Fatwa DSN-MUI mengenai wakalah serta bentuk implementasinya yang dijalankan dengan profesional.

\footnotetext{
${ }^{22}$ Wulandari, Activity Based Costing \& Activity Based Management, dalam https://www.slideshare.net/wulandari.

23 Fatwa Dewan Syariah Nasional - Majelis Ulama Indonesia (DSN-MUI) no. 10/DSN-MUI/IV/2000, tentang Wakalah.
} 
c. Sebagaimana inti dari dasar hukum yang terdapat pada Al-Qur'an surat Al-Ma'idah ayat 2 yang menegaskan wakalah merupakan bentuk tolong menolong dalam kebajikan dan taqwa, maka berdasarkan hasil wawancara peneliti menganalisis sikap tersebut diterapkan dan menjadi landasan utama Shahira dalam operasionalnya, dalam konteks ini memiliki kesesuaian dengan syariat Islam yaitu mewujudkan sikap tolong menolong dengan sesama melalui instrumen akad wakalah bil ujrah.

d. Sebagaimana yang termaktub dalam fatwa tersebut, firman Allah SWT pada surat AlBaqarah ayat 283 mengenai menjaga amanah dan kepercayaan. Menurut hasil penelitian dan data wawancara daring, Shahira selama ini selalu menjaga kepercayaan dalam melaksanakan mandat dan menunaikan amanat. Tentu hal ini bertujuan maslahat. Shahira dalam hal ini telah memenuhi ketentuan syariat Islam dikarenakan keberlangsungan usahanya yang telah dipercaya masyarakat cukup lama di Kota Surabaya ini.

e. Shahira Islamic Wedding Organizer Surabaya menurut analisis peneliti memiliki kesesuaian dengan fatwa DSN-MUI pada sisi ketentuan wakalah bil ujrah. Kesesuaian tersebut diantaranya : Pernyataan ijab dan qabul harus dinyatakan oleh para pihak untuk menunjukkan kehendak mereka dalam mengadakan kontrak (akad). Dalam hal ini tentu pihak shahibul hajat maupun Shahira Wedding Organizer sama-sama melakukan proses ijab qabul meskipun dengan pernyataan dan lafal yang disesuaikan dengan gaya bahasa sehari-hari masyarakat Kota Surabaya. Utamanya ialah tercapai kesepakatan dan kerelaan dari keduanya.

f. Wakalah dengan imbalan bersifat mengikat dan tidak boleh dibatalkan secara sepihak. Dalam konteks ini Shahira secara pribadi sama sekali tidak berniat membatalkan perjanjian dikarenakan kebutuhannya, ketersediaan event dan terkait eksisnya di masyarakat. Selain itu, Shahira dalam menerapkan wakalah bil ujrah dilakukan profesional baik pada sisi perwakilannya maupun pada sisi pembiayaannya disebabkan tujuan kualitas dan profesionalisme. Diupayakan tidak terdapat pembatalan terkecuali hal tersebut datang dari pihak shahibul hajat.

g. Berdasarkan syarat-syarat wakalah yang difatwakan, bahwasanya :

1) Bagi muwaqqil, merupakan pemilik sah urusannya. Tentu urusan yang diwakilkan kepada Shahira Wedding Organizer secara langsung berasal dari shahibul hajat dalam hal ini ialah orangtua wali dan dari calon mempelai. Konteks ini memiliki kesesuaian dengan syariat yang termaktub dalam Fatwa DSN-MUI mengenai wakalah.

2) Shahibul hajat merupakan pihak yang hak, yang berhak mendelegasikan urusannya kepada Shahira Wedding Organizer Surabaya. jelas dan konteks ini sesuai dengan syariat yang termaktub dalam Fatwa DSN-MUI mengenai wakalah.

3) Shahira Wedding Organizer sebagai waqil harus cakap hukum. konteks ini Shahira Wedding Organizer Surabaya memenuhi kriteria hukum yang berlaku di Indonesia yaitu hukum yang berkaitan dengan perijinan operasionalnya terdaftar menjadi salah satu cabang usaha dari Shahira Travel. PT. Perdana Shahira International, diterbitkan dalam Berita Negara pada tahun 2015 dengan BN 35 TBN 25244. Alamat di jalan Penjaringan Sari IIF/55 oleh Notaris. Bapak Nurmawan Hari Wismono, SH., M.KN., dengan Nomor SK : AHU-0013293.AH.01.01 dengan tipe badan hukum berupa PT. Shahira Islamic Wedding Organizer Surabaya dalam konteks ini merupakan wedding organizer resmi dalam melayani calon mempelai yang ingin melangsungkan pernikahan. Shahira memenuhi ketentuan syariat yang terdapat dalam Fatwa DSN-MUI mengenai wakalah.

4) Waqil adalah pihak yang diberi amanat perwakilan, dalam konteks ini Shahira Wedding Organizer Surabaya yang menerima amanat dari muwaqqil dan mengorganisir wewenang perwakilan.

5) Hal-hal yang diwakilkan, dalam konteks ini kedua belah pihak, baik shahibul hajat maupun Shahira Wedding Organizer Surabaya sama- 
sama saling mengetahui, bertatap muka, dan melaksanakan perjanjian secara langsung. Konteks ini kedua pihak memenuhi ketentuan syariat sesuai Fatwa DSN-MUI mengenai wakalah.

6) Hal-hal yang diwakilkan tidak bertentangan dengan syariat Islam, dalam konteks ini Shahira Wedding Organizer Surabaya selalu berupaya dalam penyiapan dan pelaksanaan pernikahan selalu selaras dengan ajaran syariat Islam.

7) Dapat diwakilkan, dalam konteks ini urusan yang dilimpahkan oleh pihak shahibul hajat merupakan sesuatu yang semestinya diwakilkan kepada

\section{KESIMPULAN}

Implementasi akad wakalah bil ujrah oleh Shahira memenuhi kriteria sesuai baik rukun dan syarat-syaratnya dengan aturan serta teori yang berlaku pada disiplin ilmu Hukum Ekonomi Syariah. Tujuan dari pelaksanaan akad wakalah bil ujrah serta akibat hukum dari adanya perjanjian tersebut tetap menghasilkan kerelaan, keikhlasan dan kepercayaan khususnya dari pihak shahibul hajat.

Ujrah merupakan pendapatan yang berhak diterima oleh Shahira Islamic Wedding Organizer Surabaya. Shahira mengkalkulasi pendapatan sebesar 5-7 \% dari total biaya dari setiap paket.

Pelaksanaan akad wakalah bil ujrah menurut perspektif Hukum Ekonomi Syariah dari sudut pandang Fatwa Dewan Syariah Nasional Majelis Ulama Indonesia (DSN-MUI) No. 10/DSN-MUI/IV/2000 mengenai wakalah disimpulkan bahwa pelaksanaan akad wakalah bil ujrah oleh Shahira Wedding Organizer Surabaya berdasar hasil analisis memiliki kesesuaian dengan Fatwa dari Dewan Syariah Nasional Majelis Ulama Indonesia (DSN-MUI) tentang wakalah dikarenakan baik dari rukun-rukun maupun syarat-syarat akad serta tujuan dari wakalah terpenuhi.

Perlu diupayakan dalam rangka menyempurnakan semakin syar'i-nya operasional Shahira Wedding Organizer Surabaya menurut
Shahira Wedding Organizer Surabaya dikarenakan keterbatasan pengetahuan, keahlian dan aspek informasi yang dimiliki oleh shahibul hajat. Konteks ini shahibul hajat bertindak benar dan memenuhi ketentuan syariat terwujudnya wakalah.

8) Jika terdapat pihak-pihak yang tidak menjalankan kewajibannya hingga terjadi perselisihan maka penyelesaian perselisihan tersebut dilaksanakan di Badan Arbitrase Syariah setelah langkah musyawarah tidak tercapai. perselisihan merupakan hal yang dihindari oleh Shahira Islamic Wedding Organizer Surabaya, bekerja dengan benar dan profesional.

perspektif Hukum Ekonomi Syariah. Terkait invoice, merupakan instrumen akad perjanjian yang sifatnya sepihak, Sedangkan menurut perspektif Hukum Ekonomi Syariah, suatu akad perjanjian harus disertakan pencatatan yang jelas dan kuat agar kelak bilamana terjadi perselisihan, maka dalam penyelesaian masalah tersebut dapat terbantu dengan adanya pencatatan.

Agar Shahira Wedding Organizer lebih sempurna ke-syar'iannya, maka perlu ditambahkan draft berbentuk MOU (memorandum of understanding) atau nota kesepahaman yang berisi mengenai perjanjian akad wakalah bil ujrah antara pihak shahibul hajat dengan pihak Shahira Islamic Wedding Organizer Surabaya yang mana memiliki muatan maksud serta tujuan yang jelas dalam upaya untuk mengesahkan akad perjanjian menjadi lebih sempurna diantara keduanya.

Pengesahan draft perjanjian wakalah bil ujrah tersebut dilakukan dengan penandatanganan oleh kedua belah pihak. Sebagaimana syarat pelaksanaan akad harus memenuhi syarat-syarat antara lain yaitu; secara lisan, diikuti dengan tindakan serta perbuatan, dan isyarat, tentu harus dilengkapi dengan syarat pencatatan berbentuk perjanjian tertulis yang menegaskan bahwa tercapainya akad wakalah bil ujrah antara kedua belah pihak secara sempurna..

\section{Sumber Literatur :}

\section{DAFTAR PUSTAKA}

Adhim, Fauzil, Muhamad, Kupinang Engkau Dengan Hamdalah, (Yogyakarta: Mitra Pustaka, 1999). 
Anshori, Ghofur, Abdul, Hukum Perjanjian Islam di Indonesia (Konsep, Regulasi dan Implementasi), (Yogyakarta: Gajah Mada University Press, 2010)

Akbar, Setiadi, Purnomo, Usman, Husaini, Metodologi Penelitian Sosial, (Jakarta: Bumi Aksara, 2000).

Tim Penyusun Fakultas Syariah dan Ekonomi Islam, Petunjuk Teknis Penelitian Skripsi, (Surabaya: UIN Sunan Ampel Surabaya Press, 2014).

Farizi, Al, Salman, Implementasi Murabahah Produktif dalam Transaksi Kredit Modal Kerja Menurut Perspektif Maqashid Syariah (Studi Analisis pada BPRS Mandiri Mitra Sukses, Gresik), (Surabaya: Universitas Muhammadiyah Surabaya, Surabaya 2017).

Hadi, Abdul, Hukum Perbankan Syariah: Akad-Akad dan Dasar Hukumnya, (Malang: Setara Press, 2018).

Dewi, Gemala, Wirdyaningsih, Narlinti, Salma, Yeni, Hukum Perikatan Islam di Indonesia, (Depok: Prenada Media Group, 2020).

Ghazaly, Rahman, Abdul, Ihsan, Ghufron, Shidiq, Sapiudin, Fiqih Muamalat, (Jakarta: Prenadamedia Group, 2010).

Fatwa DSN-MUI No: 10/DSN-MUI/IV/2000, tentang Wakalah, (Jakarta, Dewan Syariah Nasional - Majelis Ulama Indonesia, 2000).

Hidayat, Enang, Kaidah Fikih Muamalah, (Bandung: PT. Remaja Rosdakarya, 2019).

Manan, Abdul, Hukum Ekonomi Syariah (Dalam Perspektif Kewenangan Peradilan Agama), (Jakarta: Kencana, 2016).

Usman, Husaini, Akbar, Setiady, Purnomo, Metodologi Penelitian Sosial, (Jakarta: Bumi Aksara, 2000).

Moleong, J, Lexy, Metodologi Penelitian Kualitatif, (Bandung: PT. Remaja Rosdakarya, 2006).

Zulkifli, Harnanto, Manajemen Biaya, (Yogyakarta, UPP AMP YKPN, 2003).

Nurus Salihen, Analisis Akad Musyarakah Pada Pembiayaan Modal Usaha Beragunan Emas Dalam Perspektif Hukum Islam (Studi kasus di PT. BPRS Mandiri Mitra Sukses, Gresik), Jurnal Justisia Ekonomika, Vol. 4 No. 1, Juni 2020.

Galuh Vida Khumairoh, Renny Oktafia, Penerapan Akad Wakalah Bil Ujrah Pada Pengelolaan Produk Proteksi Kesehatan Di Prudential Syariah Cabang Sidoarjo, Jurnal Ekonomi Syariah Teori dan Terapan p-ISSN: 24071935, e-ISSN: 2502-1508. Vol. 7 No. 10 Oktober 2020: 1944-1960.

Pajar Hatma Indra jaya, Dinamkia Pola Pikir Orang Jawa di Tengah Arus Modernisasi, Jurnal Humaniora, Volume 24, 2 Juni 2012, 133-140.

\section{Wawancara :}

Puteri, Kartika, Meyranti, Wawancara Daring, Moskow, Russia, 17 Januari 2020, pukul 10.20 WIB (waktu Indonesia).

Puteri, Kartika, Meyranti, Wawancara Daring, Surabaya, 10 Juni 2020, pukul 06.12 WIB.

Puteri, Kartika, Meyranti, Wawancara Daring, Surabaya, 17 Juni 2020, pukul 10.30 WIB.

Puteri, Kartika, Meyranti, Wawancara Daring, Surabaya, 23 Juni 2020, pukul 10.27 WIB.

Puteri, Kartika, Meyranti, Wawancara Daring, Surabaya, 19 Juli 2020, pukul 07.10 WIB.

\section{Internet :}

Purnomo, Deni, Penerapan Akad Wakalah Bil Ujrah dalam Industri Asuransi dan Lembaga Keuangan Syariah lainnya, (Jurnal Ekonomi dan Hukum Islam, (Jakarta, 2012). http://ejournal.kopertais4.or.id.

Meilano Haryo Normala, Implementasi Akad Wakalah Dalam Pembiayaan Murabahah Di Bank Negara Indonesia (BNI) Syariah Cabang Surakarta, dalam ejournal.undip.ac.id.

Manggala, Tri Nur Wira Hisamuddin, Delon Implementasi Akuntansi Akad Wakalah Bil Ujrah Perusahaan Asuransi Syariah Berdasarkan PSAK 108: Studi di PT Asuransi Takaful Keluarga, (Jember: Jurnal ADDIN, 2014).

Kamus Besar bahasa Indonesia (KBBI), https://kbbi.web.id/.

Calysta Wedding Organizer, Pengertian Wedding Organizer, https://calystawedding.wordpress.com/, 2013.

Berita Negara, PT. Perdana Shahira International, https://iditrix.com/perdana-shahira-international. 